\title{
State Government Finances: World War II to the Current Crises
}

\author{
Thomas A. Garrett and Gary A. Wagner
}

S tates are facing their most severe budget crises in the post-World War II era. Recent data from the National Conference of State Legislatures (NCSL), however, suggest that these budget crises may be softening. Initially, in April 2003, the NCSL reported that aggregate state budget deficits for fiscal year (FY) 2003 would be in the range of $\$ 20$ to $\$ 30$ billion, and possibly as large as $\$ 78$ billion in FY 20041 ; more than half of the states were projecting a budget deficit in excess of 5 percent of general fund revenue for FY 2004, and one in four states was forecasting a deficit greater than 10 percent. In contrast to the April 2003 figures, the NCSL reported seven months later in November 2003 that state budget deficits totaled $\$ 17.5$ billion for FY 2003, states projected a cumulative deficit of $\$ 2.8$ billion for FY 2004, and only ten states were projecting budget deficits for FY $2004 .{ }^{2}$

Much of the reduction in budget deficits is a result of spending cuts, tax and fee increases, and moderate revenue growth that occurred during late 2003. The National Governors Association reported in June 2003 that more than 37 states have reduced their FY 2003 budgets by $\$ 14.5$ billion using these various instruments. ${ }^{3}$ However, the National Governors Association also reported that 19 states (a historically high number) still propose a negativegrowth budget for FY 2004.

This article will explore the extent, causes, and proposed solutions of the current fiscal crises from a historical perspective of state finance. Although the current fiscal crises are severe, it becomes more difficult to assess without a more complete understanding of the historical changes that have occurred

\footnotetext{
1 NCSL (2003a).

2 NCSL (2003b).

3 National Governors Association (2003).
}

in state revenue and expenditure streams. This article will address the role of major expenditures and revenue sources in the context of the current slowdown and how reliance on various revenue sources has changed over the past 50 years. The role of nontraditional revenue sources, such as state lotteries and casino gaming, will also be discussed. The article further addresses various fiscal institutionssuch as tax and expenditure limitation laws, rainy day funds, and balanced budget rules - and explores the role each play in state budgeting and finance.

\section{A HISTORY OF STATE FINANCES}

\section{State Expenditures}

While the underlying cause of fiscal stress is the inability of states to forecast precisely when and by how much revenue growth will decline, expenditures also play an important role in state fiscal health. As Holcombe and Sobel (1997) note, because government services such as education and health care tend to be provided at costs below comparable private sector services, the demand for government services will exceed the state's limited resources. Over the past decade, state budgets have been under considerable pressure from rapidly rising Medicaid expenditures, unfunded federal mandates in the area of health and human services, and a growing prison population.

As Table 1 demonstrates, expenditures for state governments topped $\$ 1.18$ trillion in FY 2001, with education and public welfare expenditures accounting for more than 50 percent of the typical state's budget. Education expenditures include spending on higher education, elementary and secondary education, Veteran's education benefits, and public libraries. Spending on higher education accounts for the bulk of state education spending, but there has been a trend toward a larger role for states in elementary and secondary education. Public welfare expenditures include outlays related to Medicaid,

Thomas A. Garrett is a senior economist at the Federal Reserve Bank of St. Louis, and Gary A. Wagner is an assistant professor of economics at the

A.J. Palumbo School of Business, Duquesne University. Molly D. Castelazo provided research assistance.

Federal Reserve Bank of St. Louis Review, March/April 2004, 86(2), pp. 9-25

(C) 2004, The Federal Reserve Bank of St. Louis. 


\section{Table 1}

\section{Summary of State Expenditures, FY 2001}

\begin{tabular}{lccc} 
& Amount (billions \$) & $\begin{array}{c}\text { Percent of } \\
\text { total expenditures }\end{array}$ & $\begin{array}{c}\text { Percent of } \\
\text { general expenditures }\end{array}$ \\
\hline Total expenditures & $1,184.1$ & & \\
General expenditures & $1,043.3$ & 38.1 & 35.9 \\
$\quad$ Education & 374.5 & 22.0 & 24.9 \\
Public welfare & 260.3 & 6.6 & 7.5 \\
Health and hospitals & 78.3 & 6.7 & 7.6 \\
Highways & 78.8 & 4.1 & 4.6 \\
Correction \& police protection & 48.3 & 1.9 & 2.2 \\
$\quad$ Natural resources \& parks & 22.8 & 2.6 & 2.9 \\
Interest on general debt & 30.5 & 12.7 & 14.4 \\
$\quad$ Other & 149.9 & 1.9 & 10.0
\end{tabular}

SOURCE: U.S. Census Bureau, State Government Finances: www.census.gov/govs/www/state.html.

public nursing homes, children's services such as orphanages and foster care, and services for the homeless.

The largest remaining components of expenditures, in descending order of importance, include insurance trust expenditures, highways, and health and hospitals. ${ }^{4}$ Combined with education and public welfare, these five categories constitute roughly 75 percent of state expenditures. In addition to the states' expanding role in providing education and welfare services, unfunded federal government mandates in those areas and education finance lawsuits place substantial pressure on state budgets. ${ }^{5}$

4 Insurance trust expenditures are payments made to beneficiaries of public retirement systems. Highway spending includes expenditures on the construction, operation, and repair of toll highways, non-toll highways, roads, bridges, and tunnels. Health and hospitals expenditures includes spending on the construction, operation, and repair of public hospitals (including veteran's hospitals), as well as spending on unemployment compensation and insurance, disability benefits, and veterans' benefits.

5 An unfunded federal mandate is a rule requiring state governments to provide services or goods without receiving federal compensation. See Gold (1995) for a more thorough discussion of changes in Medicaid and the role of unfunded federal mandates in the 1980s and 1990s. According to the Advocacy Center for Children's Educational Success with Standards, 29 education finance lawsuit decisions have been made since 1989. In 19 of these cases, courts ruled that education finance systems were inequitable, inadequate, or both. Additional information regarding education finance lawsuits may be found at www.accessednetwork.org.
There have been some noticeable changes in the relative importance of major spending categories over time, as demonstrated in Figure 1. In 1950, for instance, spending on education, public welfare, and highways represented near-equal shares of expenditures (roughly 20 percent for each area). The most dramatic decline since 1950 has occurred in the area of highway spending, falling from about 20 percent of the budget in 1950 to less than 8 percent today. The declining importance of highway spending is a result of a growing trend toward providing more public assistance and the fact that gasoline taxes used to finance highway spending are not indexed to inflation (which causes the real value of gasoline tax revenue to decline over time).

Education and public welfare spending have also changed considerably since 1950 . Education spending increased markedly during the 1950s and 1960s, reaching a peak of 40 percent of expenditures in 1968, as states expanded their role in providing higher education. Since the late 1960s education spending has declined slightly, except for a mild increase in the mid-1990s, and remains that largest component of state spending at just over 34 percent of general fund outlays. It should be noted that, while education spending has declined slightly in relative importance, education spending has increased over time with the growth in state budgets. 
In contrast to education, the trend in public welfare spending has experienced a sizable increase twice in the past 50 years. Following the creation of Medicaid in 1965, public welfare spending grew from 13 percent of the budget to 19 percent by 1972. ${ }^{6}$ Welfare spending remained at around 19 percent of the budget until 1990, when changes in Medicaid made more children and low-income women eligible for benefits. As a result, public welfare spending (driven almost entirely by Medicaid spending) rose from 19 percent to more than 26 percent of general expenditures during the 1990s. Snell, Eckl, and Williams (2003) contend that the rapid increase in Medicaid spending was due to expanded enrollment in the program, demographic changes, and rising health care costs.

Medicaid is an entitlement program, which means that states are compelled to provide benefits once eligibility is established, so states can do very little to control the cost of the program. Dye and McGuire (1998) find that, in response to recessions, public welfare spending rises, while education spending falls. The fact that policymakers have little discretion over public welfare spending and considerable discretion over education spending is the primary reason why education spending (particularly higher education) tends to be one of the hardest hit areas of the budget as states attempt to close deficits.

\section{State Revenue Sources}

Although revenue generated from taxation is the primary source of funds for state governments, states receive revenue from a variety of sources. As Table 2 illustrates, state governments collected nearly $\$ 1.2$ trillion in revenue during FY 2001, with just over 47 percent coming from own-source taxes. The remaining sources of revenue, listed in descending order of relative importance, include intergovernmental revenue (the bulk of which is federal grants), insurance trust revenue, revenue from user charges and fees, and revenue from state-operated liquor establishments and utility companies. ${ }^{7}$ The two largest sources of revenue, taxes and intergovern-

\footnotetext{
6 Medicaid spending now makes up roughly three-fourths of all public welfare spending, making it the single largest program provided by the states. Although Medicaid is a federal program, it is administered and partially financed by the states.

7 Intergovernmental revenue is revenue received from other governments, such as shared tax revenue and grants. Insurance trust revenue primarily includes contributions, premiums, and payroll taxes of employers and employees that participate in public retirement programs. User charges include fees or payments on such services as public school lunches, public hospitals, highways, parking, and sanitation.
}

\section{Figure 1}

\section{Sources of State Expenditure, 1950-2001}

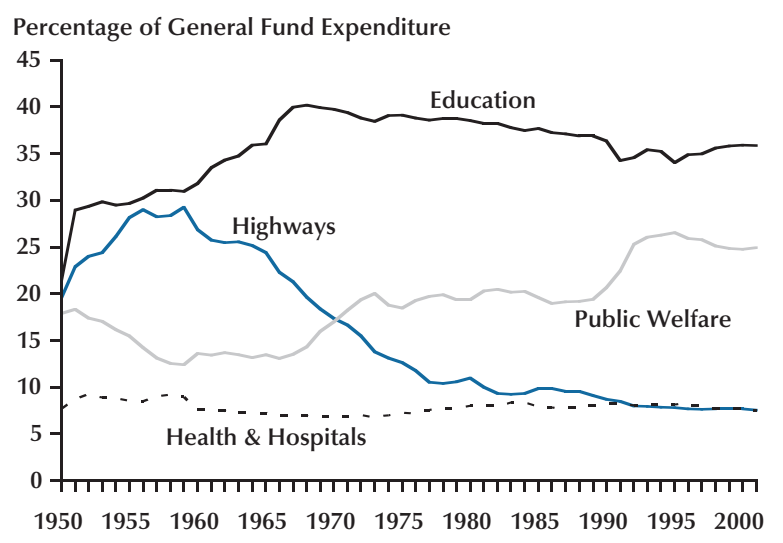

mental grants, accounted for nearly 75 percent of state revenue in FY 2001.

In terms of own-source tax revenue, the data in the column "Percent of total revenue" show the importance of various taxes as a share of total revenue, and the data in the column entitled "Percent of tax revenue" illustrate the significance of these same taxes as a share of tax revenue. For instance, while individual income taxes accounted for 17.6 percent of total state revenue in FY 2001, they accounted for more than 37 percent of all tax revenue.

As the data demonstrate, nearly 70 percent of all state tax revenue comes from two sourcesindividual income taxes and general sales taxes. A general sales tax is applicable to all sales of goods and/or services (with perhaps an exemption for food). A selective sales tax is applied (often in addition to the general sales tax) to the sale of specific items such as alcohol, tobacco, motor fuel, and pari-mutuel wagering. Selective sales taxes are also called excise taxes. If one defines sales taxes broadly to include both general and selective sales taxes, then individual income and sales taxes account for slightly more than 83 percent of state tax revenue and nearly 40 percent of total state revenue. The remaining sources of tax revenue-license taxes, corporate income taxes, and other taxes-account for 17 percent of tax revenue and 8 percent of total revenue. ${ }^{8}$

State governments have historically relied on individual income and the sale of goods and services

8 License taxes include revenue generated from the sale of licenses for selling liquor, hunting and fishing, and driving motor vehicles. Motor vehicle license taxes account for about half of all license taxes. 


\section{Table 2}

\section{Summary of State Revenue, FY 2001}

\begin{tabular}{|c|c|c|c|}
\hline & Amount (billions \$) & $\begin{array}{c}\text { Percent of } \\
\text { total revenue }\end{array}$ & $\begin{array}{l}\text { Percent of } \\
\text { tax revenue }\end{array}$ \\
\hline Total revenue & $1,180.3$ & & \\
\hline Tax revenue & 559.7 & 47.4 & \\
\hline Individual income tax & 208.1 & 17.6 & 37.2 \\
\hline General sales & 179.3 & 15.2 & 32.1 \\
\hline Selective sales & 78.7 & 6.7 & 14.1 \\
\hline License taxes & 32.9 & 2.8 & 5.8 \\
\hline Corporate income tax & 31.7 & 2.7 & 5.7 \\
\hline Other taxes* & 29.0 & 2.5 & 5.1 \\
\hline Intergovernmental revenue & 305.6 & 25.9 & \\
\hline Insurance trust revenue & 120.0 & 10.2 & \\
\hline User charges and fees & 93.1 & 7.9 & \\
\hline Miscellaneous revenue ${ }^{\dagger}$ & 90.9 & 7.7 & \\
\hline Liquor \& utility revenue & 11.0 & 0.9 & \\
\hline
\end{tabular}

as primary tax bases. As Table 3 indicates, of the 43 states that currently utilize some form of an individual income tax, nearly three-fourths had their tax in place before World War II. Apart from the numerous rate and base changes that occurred, the most recent major changes in state individual income taxes occurred between 1961 and 1976, when 11 states began taxing personal income for the first time. Connecticut was the last state to make significant changes to their individual income tax when, in 1991, the state began taxing wage and salary income in addition to previously taxed interest and dividend income.

Along with the individual income tax, state governments have historically relied on corporate income as a source of funds. Of the 45 states that currently tax corporate income, more than 80 percent initially adopted the tax prior to World War II; the last two states to tax this base, Ohio and Florida, did so in 1971. Revenue generated from the taxation of corporate income presently accounts for less than 6 percent of state tax revenue and has never accounted for more than 9 percent. In addition, although gasoline tax revenue was not explicitly listed in Table 3, revenue from the taxation of motor fuel was a large component of state tax revenue, especially before the mid-1970s. All 50 states currently tax the sale of gasoline, and only Alaska and Hawaii did not have a gasoline tax in place before 1930.

The final tax base noted in Table 3, the general sales tax, is the newest major base to be added to states' portfolios of funding sources. Of the 45 states that currently impose a general sales tax, 21 adopted the tax in the post-World War II era. The adoption pattern of the general sales tax falls primarily into two distinct time periods - a first wave of states that adopted the tax during the Great Depression and a second wave that adopted the tax to help advance the expansion of government services that occurred in the 1960s.

While the data in Table 2 show that individual income taxes and general sales taxes are currently the largest components of state tax revenue, the relative importance of various taxes has shifted considerably over time. In 1950, for example, revenue from general sales taxes accounted for the largest share of general fund revenue, followed by the motor fuel tax, excise taxes on alcohol and tobacco, the individual income tax, and finally the corporate income tax. The relative importance of 


\section{Table 3}

Adoption Dates of Selected State Taxes

\begin{tabular}{|c|c|c|c|c|}
\hline & Individual income & Corporate income & General sales & Gasoline \\
\hline Alabama & 1933 & 1933 & 1936 & 1923 \\
\hline Alaska & $1949 *$ & 1949 & & 1946 \\
\hline Arizona & 1933 & 1933 & 1933 & 1921 \\
\hline Arkansas & 1929 & 1929 & 1935 & 1921 \\
\hline California & 1935 & 1929 & 1933 & 1923 \\
\hline Colorado & 1937 & 1937 & 1935 & 1919 \\
\hline Connecticut & $1969^{+}$ & 1915 & 1947 & 1921 \\
\hline Delaware & 1917 & 1957 & & 1923 \\
\hline Florida & & 1971 & 1949 & 1921 \\
\hline Georgia & 1929 & 1929 & 1951 & 1921 \\
\hline Hawaii & 1901 & 1901 & 1935 & 1932 \\
\hline Idaho & 1931 & 1931 & 1965 & 1923 \\
\hline Illinois & 1969 & 1969 & 1933 & 1927 \\
\hline Indiana & 1963 & 1963 & 1933 & 1923 \\
\hline lowa & 1934 & 1934 & 1933 & 1925 \\
\hline Kansas & 1933 & 1933 & 1937 & 1925 \\
\hline Kentucky & 1936 & 1936 & 1960 & 1920 \\
\hline Louisiana & 1934 & 1934 & 1938 & 1921 \\
\hline Maine & 1969 & 1969 & 1951 & 1923 \\
\hline Maryland & 1937 & 1937 & 1947 & 1922 \\
\hline Massachusetts & 1916 & 1919 & 1966 & 1929 \\
\hline Michigan & 1967 & $1967 \S$ & 1933 & 1925 \\
\hline Minnesota & 1933 & 1933 & 1967 & 1925 \\
\hline Mississippi & 1912 & 1921 & 1930 & 1922 \\
\hline Missouri & 1917 & 1917 & 1934 & 1925 \\
\hline Montana & 1933 & 1917 & & 1921 \\
\hline Nebraska & 1967 & 1967 & 1967 & 1925 \\
\hline Nevada & & & 1955 & 1923 \\
\hline New Hampshire & $1923^{\ddagger}$ & 1970 & & 1923 \\
\hline New Jersey & 1976 & 1958 & 1966 & 1927 \\
\hline New Mexico & 1933 & 1933 & 1933 & 1919 \\
\hline New York & 1919 & 1917 & 1965 & 1929 \\
\hline North Carolina & 1921 & 1921 & 1933 & 1921 \\
\hline North Dakota & 1919 & 1919 & 1935 & 1919 \\
\hline Ohio & 1971 & 1971 & 1934 & 1925 \\
\hline Oklahoma & 1915 & 1931 & 1933 & 1923 \\
\hline Oregon & 1930 & 1929 & & 1919 \\
\hline Pennsylvania & 1971 & 1935 & 1953 & 1921 \\
\hline Rhode Island & 1971 & 1947 & 1947 & 1925 \\
\hline South Carolina & 1922 & 1922 & 1951 & 1922 \\
\hline South Dakota & & & 1933 & 1922 \\
\hline Tennessee & $1931^{\ddagger}$ & 1923 & 1947 & 1923 \\
\hline Texas & & & 1961 & 1923 \\
\hline Utah & 1931 & 1931 & 1933 & 1923 \\
\hline Vermont & 1931 & 1931 & 1969 & 1923 \\
\hline Virginia & 1916 & 1915 & 1966 & 1923 \\
\hline Washington & & & 1933 & 1921 \\
\hline West Virginia & 1961 & 1967 & 1933 & 1923 \\
\hline Wisconsin & 1911 & 1911 & 1961 & 1925 \\
\hline Wyoming & & & 1935 & 1923 \\
\hline \multicolumn{5}{|c|}{ 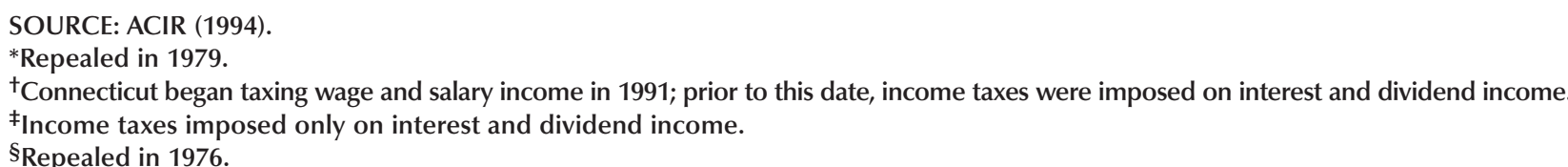 } \\
\hline
\end{tabular}




\section{Figure 2}

\section{Sources of State Tax Revenue, 1950-2001}

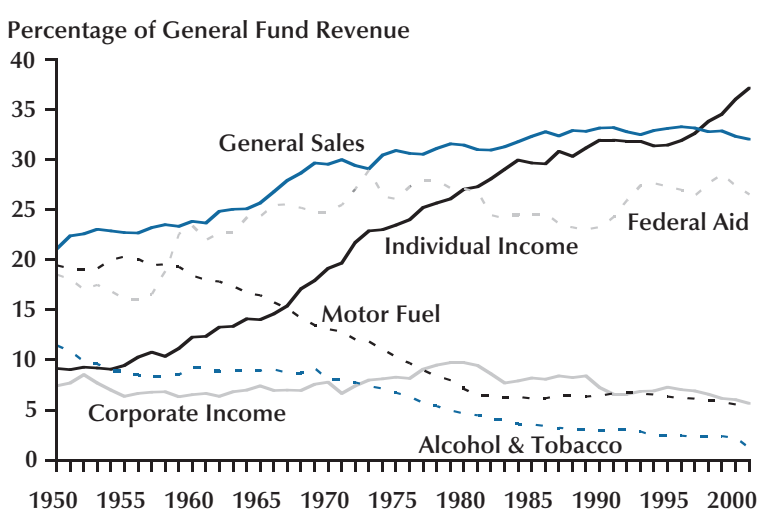

major state revenue sources over the period 1950 to 2001, each measured as a share of general fund revenue, is illustrated in Figure 2. ${ }^{9}$

As Figure 2 shows, the relative importance of federal aid and tax revenue from individual income and general sales has increased considerably over the past 50 years, while revenue generated from the sale of alcohol, tobacco, and motor fuel has diminished in importance. During the 1950s, for instance, nearly 30 percent of general fund revenue was derived from alcohol, tobacco, and motor fuel taxes, compared with roughly 6 percent in 2001 . The decline in tobacco tax revenue is due in part to individuals becoming more health conscious, and the decline in motor fuel tax revenue as a share of general fund revenue can be partly attributed to more fuel-efficient automobiles. Another explanation for their diminishing importance is that these taxes are linked to the quantity of goods consumed rather than the price of the goods. As a result, these taxes fail to keep pace with inflation.

The most striking series in Figure 2 are individual income and general sales tax revenue. The importance of individual income tax revenue has risen steadily over the past five decades and is now the single most important tax base. Climbing from 9 percent of general fund revenue in the early 1950s, revenue from individual income taxes surpassed revenue from general sales taxes in the mid-1990s before reaching its peak of 37 percent of general fund revenue in 2001 . While increases in income tax rates and expansions in the income tax base have obvi-

\footnotetext{
9 The share of general fund revenue, as opposed to total revenue, is used because a consistent series of total state revenue is not available prior to 1965 .
}

ously contributed to the growing importance of this revenue source, the most rapid period of growth in individual income tax revenue occurred between 1960 and the mid-1970s when ten states initially adopted the tax. However, Figure 2 also reveals that the growth in income tax revenue during the economic expansion of the 1990s (when no states adopted personal income taxes) is near the growth during the 1960s and 1970s. Income tax revenue accounted for an increasingly higher percentage of general fund revenue during the economic boom of the 1990s, due to rapidly growing salaries and capital gains from stock options and bonuses.

In contrast to the individual income tax, the relative importance of general sales tax revenue has risen at a much steadier rate. At just over 22 percent of general fund revenue in 1950, revenue from general sales taxes now constitutes roughly 32 percent. In fact, the expansion in general sales tax revenue that occurred between 1950 and 1980 appears to have slowed and even declined slightly in the past decade. This trend can be attributed to the move toward a service-oriented economy on which general sales taxes are not typically applied, and also possibly to the growth in electronic commerce, which is generally not subject to sales taxes. ${ }^{10}$

Federal aid and corporate income taxes have not exhibited such a strong upward or downward trend as the other revenue sources. There is no question, based on Figure 2, that revenue from federal grants has fluctuated more than other revenue sources. However, the average revenue obtained through federal grants over the period ( 24 percent of general fund revenue) is only 1 to 2 percent lower than federal grant revenues during the economic boom of the 1990s. Similarly, revenue from corporate income taxes is currently less than 6 percent of general fund revenue and averaged 7.4 percent over the sample period.

Cyclical Variability of Tax Revenues. While historical shifts in the relative importance of revenue sources may seem disconnected from the current crisis and economic downturns in general, the composition of a state's revenue sources has a significant bearing on how revenue streams fluctuate with changes in economic activity (Holcombe and Sobel, 1997; Crain, 2003). If revenue streams in one state decrease more during downturns than revenue

\footnotetext{
${ }^{10}$ Buyers are required to pay sales taxes on electronic commerce if the firm has a physical presence (termed "nexus") in the buyer's state. See Goolsbee (2000) for a discussion of the issues surrounding taxation of electronic commerce. Industry and political developments on the issue can be found at www.ecommercetax.com.
} 
streams in another state, then the state with the more volatile revenue stream would be expected to experience a much more severe fiscal crisis during any given recession. The amount by which revenue from a specific tax varies with the business cycle is referred to as the cyclical variability of the tax.

Since different sources of tax revenue are derived from different tax bases, each of which reacts differently to changes in the business cycle, the various sources of revenue for state governments will react differently to business cycle swings. Thus, if the portfolio of state revenues becomes more dependent on a revenue source that has a high cyclical variability, then in most cases the overall portfolio of revenue will also become more sensitive to changes in the business cycle. Following Holcombe and Sobel (1997), the cyclical variability of a tax in a given state is measured by estimating the regression

$$
\Delta \ln \left(\text { Base }_{t}\right)=\alpha+\beta \cdot \Delta \ln \left(Y_{t}\right)+\varepsilon_{t},
$$

where Base $_{t}$ is the tax base (taxable income, retail sales, etc.) for a particular tax at time $t$ and $Y_{t}$ denotes state real personal income at time $t .{ }^{11}$ The estimated coefficient $(\beta)$ is the measure of the cyclical variability of the particular tax base. Since $\Delta \ln \left(\right.$ Base $\left._{t}\right)$ and $\Delta \ln \left(Y_{t}\right)$ are the percentage changes in the tax base and personal income, respectively, $\beta$ measures the percentage change in the tax base given a percentage change in personal income. ${ }^{12} \mathrm{~A}$ value of $\beta$ that is larger than 1 in absolute value indicates that revenue from a particular tax base is more volatile than aggregate economic activity, while a value smaller than 1 in absolute value indicates that it is less volatile.

With regard to the measure of cyclical variability in general, the tax base (and thus tax revenue) is procyclical if $\beta>0$, countercyclical if $\beta<0$, and independent of the business cycle if $\beta=0$. Research has revealed that revenue tends to be procyclical for most sources of tax revenue.

Table 4 shows the cyclical variability of several sources of state tax revenue estimated by Holcombe and Sobel (1997). These estimates are based on the national aggregate of state tax bases, so gross domes-

\footnotetext{
11 Tax revenue can be used instead of the tax base. However, this requires accounting for discretionary changes in tax policies and tax rates that occur over time. While tax bases may change over time, Holcombe and Sobel (1997) use broad-based tax bases rather than narrow-based tax bases to overcome this problem.

12 Holcombe and Sobel (1997) refer to the estimated slope coefficient in equation (1) as the "short-run elasticity" to distinguish it from the "long-run elasticity" that measures how a particular revenue source grows over time. The long-run elasticity is found by estimating the above regression with the tax base and business-cycle variables in levels rather than first differences.
}

\section{Table 4}

\section{Cyclical Variability of Selected State Revenue Sources}

\begin{tabular}{lc} 
Revenue source & $\begin{array}{c}\text { Estimate of } \beta \\
\text { (standard error) }\end{array}$ \\
\hline Individual income tax & $1.164(0.161)$ \\
General sales tax (with food) & $1.229(0.098)$ \\
General sales tax (without food) & $1.612(0.111)$ \\
Corporate income tax & $3.369(0.685)$ \\
Motor fuel tax & $0.729(0.175)$ \\
Liquor & $-0.586(0.225)$
\end{tabular}

SOURCE: Holcombe and Sobel (1997, p. 92). $\beta$ is obtained from the regression of $\Delta \ln \left(\right.$ Base $\left._{t}\right)=\alpha+\beta \cdot \Delta \ln \left(G D P_{t}\right)+\varepsilon_{t}$.

tic product (GDP) rather than state personal income was used in the regression equations. Each coefficient is statistically significant and, with the exception of the motor fuel and liquor taxes, all revenue sources are more variable than the business cycle. In the case of the corporate income tax, a 1-percentagepoint decline in GDP will, on average, reduce corporate income tax revenue by more than 3 percentage points.

General sales tax revenue is considerably more stable when food is part of the tax base. This highlights a general but important theme regarding the variability of revenue - the more broadly a particular tax base is defined, the lower the cyclical variability of the revenue from that base. ${ }^{13}$ The implication of a changing composition of state tax revenue should be very clear at this point: Over the past 50 years, states' reliance on motor fuel and alcohol and tobacco revenue has diminished, while reliance on individual income and general sales taxes has expanded. Thus, the typical state's tax portfolio has shifted away from revenue sources that are less cyclical than the economy and toward revenue sources that are more cyclical than the economy. ${ }^{14}$

\footnotetext{
${ }^{13}$ Although there are a number of strategies that state policymakers may follow to reduce the cyclical variability of tax revenue, which in turn would smooth the overall revenue stream, such a discussion extends beyond the scope of this paper. See Holcombe and Sobel (1997) and Sobel and Wagner (2003) for additional details.

14 Over time, however, the share of output generated from the relatively less cyclically sensitive service-producing industries has risen modestly in comparison with relatively larger cyclically sensitive good-producing industries. This would suggest that growth from individual income and corporate tax revenues (about 75 percent of total state revenues) should become less cyclical over time as well.
} 


\section{Table 5}

\section{State Lottery Start-Up Dates and FY 2002 Sales}

\begin{tabular}{|c|c|c|c|c|c|}
\hline State & $\begin{array}{l}\text { First year } \\
\text { of lottery }\end{array}$ & $\begin{array}{c}\text { FY } 2002 \text { sales } \\
\text { (\$ millions) }\end{array}$ & State & $\begin{array}{l}\text { First year } \\
\text { of lottery }\end{array}$ & $\begin{array}{c}\text { FY } 2002 \text { sales } \\
\text { (\$ millions) }\end{array}$ \\
\hline Arizona & 1981 & 294.82 & Montana & 1987 & 33.63 \\
\hline California & 1985 & $2,915.90$ & Nebraska & 1993 & 73.91 \\
\hline Colorado & 1983 & 407.97 & New Hampshire & 1964 & 212.90 \\
\hline Connecticut & 1972 & 907.90 & New Jersey & 1970 & $2,068.52$ \\
\hline Delaware* & 1975 & 674.01 & New Mexico & 1996 & 133.97 \\
\hline Florida & 1988 & $2,330.36$ & New York & 1967 & $4,753.62$ \\
\hline Georgia & 1993 & $2,449.36$ & Ohio & 1974 & $1,983.11$ \\
\hline Idaho & 1989 & 92.67 & Oregon* & 1985 & 816.94 \\
\hline Illinois & 1974 & $1,590.15$ & Pennsylvania & 1972 & $1,934.16$ \\
\hline Indiana & 1989 & 626.31 & Rhode Island* & 1974 & $1,171.10$ \\
\hline lowa & 1985 & 181.22 & South Carolina ${ }^{\dagger}$ & 2002 & 319.99 \\
\hline Kansas & 1987 & 190.08 & South Dakota* & 1987 & 629.96 \\
\hline Kentucky & 1989 & 638.72 & Texas & 1992 & $2,966.27$ \\
\hline Louisiana & 1991 & 311.62 & Vermont & 1978 & 81.99 \\
\hline Maine & 1974 & 157.90 & Virginia & 1988 & $1,108.07$ \\
\hline Maryland & 1973 & $1,306.55$ & Washington & 1982 & 438.61 \\
\hline Massachusetts & 1972 & $4,213.22$ & Washington, DC & 1982 & 211.13 \\
\hline Michigan & 1972 & $1,688.04$ & West Virginia* & 1986 & 848.63 \\
\hline Minnesota & 1990 & 377.36 & Wisconsin & 1988 & 427.57 \\
\hline Missouri & 1986 & 585.19 & Total & & $42,153.43$ \\
\hline
\end{tabular}

SOURCE: North American Association of State and Provincial Lotteries (www.naspl.org), state lottery websites, and Clotfelter and Cook (1989, Chap. 8).

*Includes video lottery sales.

†Sales began January 2002.

\section{Nontraditional Revenue Sources}

State Lotteries. The first state lottery began in New Hampshire in 1964, and since that time 38 states and the District of Columbia currently have state lotteries, with Tennessee and North Dakota scheduled to begin lottery operations within the next year or two. Lottery sales in the United States totaled $\$ 42$ billion in FY 2002, with states collecting over $\$ 13$ billion in net lottery revenues. ${ }^{15}$ The primary objective of state lotteries is to generate revenue, and lotteries are seen by proponents and state officials as a voluntary way to raise this rev-

${ }^{15}$ From the North American Association of State and Provincial Lotteries (www.naspl.org): Net lottery revenue is gross sales minus prize payouts and other expenses such as retailer commissions, advertising, and general operations. enue. Many states earmark lottery revenue for certain social programs such as education, senior citizen care, and economic development. On average, net lottery revenue accounts for roughly 2 percent of total state tax revenue. ${ }^{16}$ FY 2002 lottery sales and start-up dates are shown in Table 5.

Several reasons have been cited to explain state lottery adoption. First, although lottery revenue is significantly more variable than non-lottery revenue, a low correlation between lottery and nonlottery revenue suggests that the variability in lottery revenue will not destabilize overall revenue. ${ }^{17}$ Thus,

\footnotetext{
${ }^{16}$ See Clotfelter and Cook (1990) for a discussion on state lotteries and state lottery financing.

${ }^{17}$ Szakmary and Szakmary (1995).
} 
lotteries are an attractive means for states to diversify their revenue portfolio. Further research has shown that the first states to adopt lotteries did so independently in response to fiscal pressures, but in later years states have adopted lotteries in response to the fear of lost revenue from lotteries in neighboring states. ${ }^{18}$ This may be due to the fact that many states had begun to exhaust their traditional revenue sources and thus began to explore nontraditional sources of revenue. Adopting a nontraditional revenue source is arguably more politically appealing than raising rates on existing taxes or expanding current tax bases.

Using state lotteries to raise government revenue has been criticized for several reasons. First, research has shown that lotteries place a greater financial burden on the poor; that is, lower income individuals spend a higher percentage of their income on lottery tickets than higher income individuals. ${ }^{19}$ While the regressivity of lotteries is also true for sales, excise, and payroll taxes, state governments do not actively promote these activities as they do their lotteries.

Second, while states justify the existence of lotteries by earmarking lottery revenues (e.g., for education), studies have shown that lotteries have not increased expenditures in these targeted areas. ${ }^{20}$ This is because, like many revenue sources, lottery revenues are interchangeable within the state budget. State legislators can simply reduce the total amount of funds budgeted for, say, education by a certain amount and use the remaining funds elsewhere; then they can use lottery revenues to bring total education expenditures back to their pre-lottery levels.

Finally, the expected return to the player of most lottery games is about 50 cents on a $\$ 1$ ticket. This 50 percent payback rate is much lower than on other gambling activities such as casino gaming, which has an average return of about 90 to 95 percent. Unlike casino gaming, which is regulated by the state, lotteries are essentially a state-run monopoly. Consumer welfare would certainly be enhanced if the payback rate on lotteries were higher, but this conflicts with the current revenue maximization goal of state lotteries. ${ }^{21}$

Casino Gaming. Casino gaming has become a major industry in the United States over the past

\footnotetext{
${ }^{18}$ Alm, McKee, and Skidmore (1993).

${ }^{19}$ Clotfelter and Cook (1989, Chap. 6).

${ }^{20}$ Spindler (1995) and Garrett (2001).

${ }^{21}$ Clotfelter and Cook (1989, Chap. 11).
}

two decades. Prior to the late 1980s, casino gaming was legal only in Nevada and Atlantic City, New Jersey. The 1990s saw a marked increase in the number of states that legalized casino gaming. Riverboat casino gaming first began in Iowa and Illinois in 1991 and quickly spread throughout the Midwest. Riverboat gaming now also exists in Indiana, Mississippi, and Missouri. Louisiana and Michigan legalized land-based casino gaming within the last decade.

Annual gaming net revenue (gross wagers minus player winnings) has grown from \$9 billion in 1991 to over $\$ 40$ billion in 2001 . The casino industry consists of two major parties-Indian tribes and publicly traded private corporations such as Harrah's Entertainment and Trump Hotels and Casino Resorts. The Indian Gaming Regulatory Act (Public Law 100-497) passed in 1988 allows Indian tribes to own and operate casinos on their reservations. Tribal gaming is now available in 25 states and generated nearly $\$ 13$ billion in revenue during 2001. Corporate casino gaming is available in nine states and generated over $\$ 27$ billion in revenue in 2001 .

While tribal gaming is available in more states, corporate casino gaming has traditionally been perceived as a more appropriate tool for fostering general economic development through increased employment and tax revenues. ${ }^{22}$ The primary reason for this is that states have no power to tax Indian casino revenue because Indian casinos are sovereign entities from the state. ${ }^{23}$ While states and Indian tribes do cooperate in regulation and security issues (dictated by state-tribal gaming compacts), the relationship between a tribe and a state is very similar to the relationship between two states-one state generally cannot legally dictate what another state can do.

Corporate casinos, however, are private industries that are taxed and regulated by a state. As seen in Table 6, casino revenues are quite sizeable, making them an attractive revenue source. Most states have a graduated casino revenue tax schedule, with marginal tax rates ranging from about 5 percent to over

\footnotetext{
22 Indian tribes use gaming revenue from their casinos to foster economic development on their reservations. Economic development from corporate casino gaming, however, has the potential to effect a much greater population.

${ }^{23}$ States have negotiated payments from tribes in return for certain services such as security and maintaining and improving highway access to casinos. Also, the current state budget crises have prompted several states, such as California, to consider the direct taxation of Indian casino revenue.
} 


\section{Table 6}

\section{Casino Revenue-Selected States}

\begin{tabular}{cccc} 
State & $\begin{array}{c}\text { 2001 Revenue } \\
\text { (\$ millions) }\end{array}$ & $\begin{array}{c}\text { 2000 Revenue } \\
\text { (\$ millions) }\end{array}$ & Percent change \\
\hline Colorado & 675.3 & 631.7 & 6.9 \\
Connecticut & $1,401.6$ & $1,308.7$ & 7.1 \\
Illinois & $1,783.8$ & $1,657.8$ & 7.6 \\
Indiana & $1,841.8$ & $1,689.7$ & 9.0 \\
lowa & 922.9 & 892.6 & 3.4 \\
Louisiana & $1,883.2$ & $1,708.9$ & 10.2 \\
Michigan & $1,007.4$ & 742.9 & 35.6 \\
Mississippi & $2,700.8$ & $2,650.4$ & 1.9 \\
Missouri & $1,137.1$ & 996.6 & 14.1 \\
Nevada & $9,466.9$ & $9,599.4$ & -1.4 \\
New Jersey & $4,303.9$ & $4,299.6$ & 0.1
\end{tabular}

NOTE: Tribal and corporate casino revenue are considered in the above figures, which represent revenues to the casinos net of player winnings.

SOURCE: Adler (2003, p. 6).

50 percent. As with state lotteries, many states earmark their casino tax revenue for social programs, such as education.

The primary reason that many states have approved corporate casino gaming is that it is seen as a potential tool for economic growth. The greatest perceived benefits are increased employment, greater tax revenue to state and local governments, and growth in local retail sales. Increasing fiscal pressures on state budgets during the 1990-91 recession, the fear of lost revenue to neighboring states' casinos, and a more favorable public attitude regarding casino gaming have all increased the appeal and acceptance of casinos over the past decade.

\section{THE ROLE OF FISCAL INSTITUTIONS}

Unlike the federal government, the options available to state governments during periods of fiscal stress are often limited by their institutional structures. The most well-known fiscal constraints facing state policymakers are balanced budget laws and tax and expenditure limit laws (TELs). From the perspective of economic downturns, balanced budget rules and TELs typically require state policymakers to cut expenditures, increase taxes, or use some combination of both to offset the period of fiscal stress.
Every state, with the exception of Vermont, is subject to some form of balanced budget rule. The Advisory Commission on Intergovernmental Relations (ACIR, 1987) classifies state balanced budget rules into five categories: (1) the governor is required to submit a balanced budget; (2) the legislature is required to adopt a balanced budget; (3) the state may carry forward a budget deficit to be corrected in the next fiscal year; (4) the state may not carry forward a budget deficit into the next budget cycle (which is 2 years for the 20 states operating on a biennial cycle); and (5) the state may not carry forward a budget deficit into the next fiscal year. Categories 1 and 2 are examples of ex ante rules placing constraints on behavior prior to the fiscal year and do not require any actions to remedy an end-of-the-year deficit. Category 3 permits perpetual debt financing as long as planned expenditures in the next fiscal year plus the current deficit do not exceed expected revenue. The final two categories, 4 and 5, require states to take some action during the current fiscal year if an end-of-the-year deficit is projected. The type of balanced budget rule for each state (designated by number) and the adoption dates of TELs and rainy day funds are provided in Table 7 .

In addition to balanced budget rules, a number 


\section{Table 7}

Selected State Fiscal Institutions

\begin{tabular}{|c|c|c|c|c|}
\hline & $\begin{array}{c}\text { Balanced budget } \\
\text { rule }\end{array}$ & $\begin{array}{c}\text { Expenditure } \\
\text { limit }\end{array}$ & Tax limit & $\begin{array}{c}\text { Rainy day } \\
\text { fund }\end{array}$ \\
\hline Alabama & 5 & & & \\
\hline Alaska & 1,3 & 1982 & & 1986 \\
\hline Arizona & 5 & 1978 & & \\
\hline Arkansas & 5 & & & 1990 \\
\hline California & 1,3 & 1979 & & 1985 \\
\hline Colorado & 5 & 1991, 1992 & 1992 & 1983 \\
\hline Connecticut & $1,2,3$ & 1991, 1992 & & 1979 \\
\hline Delaware & 5 & 1978 & & 1977 \\
\hline Florida & 5 & & 1994 & 1959 \\
\hline Georgia & 5 & & & 1976 \\
\hline Hawaii & $1,4,5$ & 1978 & & 2000 \\
\hline Idaho & 2 & 1980 & & 1984 \\
\hline Illinois & 1,2 & & & 2000 \\
\hline Indiana & 5 & & & 1982 \\
\hline lowa & 5 & 1992 & & 1992 \\
\hline Kansas & 5 & & & 1993 \\
\hline Kentucky & 4,5 & & & 1983 \\
\hline Louisiana & 2 & 1993 & 1979 & 1990 \\
\hline Maine & 5 & & & 1986 \\
\hline Maryland & $1,2,3$ & & & 1985 \\
\hline Massachusetts & 1 & & 1986 & 1986 \\
\hline Michigan & 3 & & 1978 & 1977 \\
\hline Minnesota & 4 & & 1980, 1986 & 1981 \\
\hline Mississippi & 5 & 1992 & & 1982 \\
\hline Missouri & 5 & 1981 & & 1992 \\
\hline Montana & $2,4,5$ & & & \\
\hline Nebraska & 5 & 1979 & & 1983 \\
\hline Nevada & 1,2 & & & 1994 \\
\hline New Hampshire & 1 & 1990 & & 1987 \\
\hline New Jersey & 5 & & & 1990 \\
\hline New Mexico & 5 & & & 1978 \\
\hline New York & 1 & & & 1945 \\
\hline North Carolina & 5 & 1991 & & 1991 \\
\hline North Dakota & 4 & & & 1987 \\
\hline Ohio & 5 & & & 1981 \\
\hline Oklahoma & 5 & 1985 & & 1985 \\
\hline Oregon & 4 & 1979 & & \\
\hline Pennsylvania & $1,2,3$ & & & 1985 \\
\hline Rhode Island & 5 & 1992 & & 1985 \\
\hline South Carolina & 3,5 & 1980, 1984 & & 1978 \\
\hline South Dakota & 5 & & & 1991 \\
\hline Tennessee & 3,5 & 1978 & & 1972 \\
\hline Texas & 2,4 & & & 1987 \\
\hline Utah & 5 & 1989 & & 1986 \\
\hline Vermont & & & & 1988 \\
\hline Virginia & 4 & & & 1992 \\
\hline Washington & 3 & 1993 & & 1981 \\
\hline West Virginia & 5 & & & 1994 \\
\hline Wisconsin & 3 & & & 1981 \\
\hline Wyoming & 4 & & & 1982 \\
\hline
\end{tabular}

NOTE: The five balanced budget rules are: (1) the governor is required to submit a balanced budget; (2) the legislature is required to adopt a balanced budget; (3) the state may carry forward a budget deficit to be corrected in the next fiscal year; (4) the state may not carry forward a budget deficit into the next budget cycle (which is 2 years for the 20 states operating on a biennial cycle); and (5) the state may not carry forward a budget deficit into the next fiscal year.

SOURCE: ACIR (1994), Wagner (2003), Rueben (1997). 
of states have TELs in place (generally adopted during the "tax revolt" era of the late 1970s) that are designed to limit the growth in state spending and/or tax revenue collection. In general, TELs specify the maximum increase in the rate of growth in the state's tax revenues and expenditures from one year to the next. The limits vary widely across states but are typically based on the growth in real personal income or population growth plus inflation.

Research investigating balanced budget rules and TELs suggests that such institutional structures alter states' responses in periods of fiscal stress. 24 For instance, Poterba (1994) finds that states with strict balanced budget rules, which are categories 4 and 5 in Table 7, adjust taxes and expenditures more strongly in response to an unanticipated budget shortfall than do states with ex ante balanced budget rules. Moreover, states with TELs typically experience slower rates of tax revenue growth as a result of the constraints and are less likely to increase taxes (and more likely to reduce expenditures) in response to unanticipated budget shortfalls.

In an effort to reduce reliance on expenditure reductions and/or tax increases to mitigate periods of fiscal stress, states typically save surplus revenue during good years for use during lean years when revenue growth is below average. While such surplus funds have historically been maintained as a general fund surplus, nearly all states have supplemented this practice with use of a rainy day fund (RDF), which is nothing more than a separate account in state budgets where surplus funds may be retained. The basic idea underlying the difference between the general fund and a RDF is this: Surplus monies that states intend to save long term are retained in a RDF, while monies retained for the short term are placed in the general fund. Both general fund and RDF balances typically earn interest following the state's investment policies regarding surplus funds.

As Table 7 shows, of the 46 states that currently have a RDF, only a handful were in place before 1980 . States with RDFs generally deposit some fraction of a general fund surplus into the RDF and retain the remainder in the general fund. Thus, for states with RDFs, the total funds available to correct unexpected shortfalls at any given time equals the sum of the state's general fund and RDF balance, which Gold (1995) argues is the best indicator of a state's overall fiscal health.

\footnotetext{
24 For additional evidence regarding the effects of balanced budget rules, see Levinson (1998). The effectiveness of TELs is explored in Elder (1992) and Rueben (1997).
}

States' RDF balances have dropped significantly in the past two years as states attempted to mitigate their budget crises. In January 2002, total RDF balances topped $\$ 17$ billion. Aggregate balances dropped to $\$ 11.4$ billion at the end of FY 2002, and fell further to $\$ 8.5$ billion at the end of FY 2003. For FY 2004, 13 states are expected to tap their RDFs to minimize budget shortfalls. However, many states are reluctant to reduce RDF balances further, and many states (Arizona, Idaho, and Oklahoma, for example) have depleted their balances altogether. 25

The central issue regarding $\mathrm{RDFs}$ and their ability to assist states in easing recessionary pressures is the extent to which monies saved in RDFs are simply replacing monies saved in the general fund. Much like the fungibility of lottery revenues, since RDFs are nothing more than separate accounts in state budgets (just like the general fund), policymakers may simply reduce the size of the general fund surplus by $\$ 1$ for every $\$ 1$ deposited in the RDF. In fact, Wagner (2003) finds that for every dollar that states deposited into their RDF, total savings (the sum of the state's RDF and general fund balance) increased by only $\$ 0.44$ to $\$ 0.49$. This clearly suggests that, for the average state, RDFs have not played a significant role in improving fiscal health.

Apart from the issue of substitutability with the general fund, the most important point regarding RDFs and savings is not so much how the funds are saved, but whether or not sufficient funds are saved at all. The notion of optimal savings for states has not been widely addressed in the literature, with the exception of Holcombe and Sobel (1997). The conclusion reached by these authors is that certain types of RDFs will improve a state's ability to weather downturns, specifically those RDFs having rules that force policymakers to save and limit how the funds may be spent. However, the typical state's savings are grossly insufficient to substantially lessen the need for expenditure reductions and/or tax increases.

\section{THE STATE BUDGET CRISES ${ }^{26}$}

\section{Scope of the Crises}

The year 2003 was arguably the worst year for state budgets and budget forecasts in recent history.

\footnotetext{
25 NCSL (2003c).

${ }^{26}$ All data in this section has been obtained from the NCSL (2003a, b; www.ncsl.org/programs/fiscal/budissus.htm) and the Center on Budget and Policy Priorities (2002, www.cbpp.org/11-14-02sfp.htm).
} 


\section{Table 8}

\section{Summary of Projected FY 2004 State Budget Deficits as of April 2003}

\begin{tabular}{lccc} 
Budget deficit (millions \$) & $\begin{array}{c}\text { Number } \\
\text { of states }\end{array}$ & $\begin{array}{c}\text { Budget deficit as a } \% \\
\text { of general fund }\end{array}$ & $\begin{array}{c}\text { Number } \\
\text { of states }\end{array}$ \\
\hline$>\$ 5,000$ & 2 & $>20 \%$ & 4 \\
$\$ 1,000-\$ 5,000$ & 8 & $15-20 \%$ & 3 \\
$\$ 500-\$ 1,000$ & 8 & $10-15 \%$ & 6 \\
$\$ 100-\$ 500$ & 10 & $5-10 \%$ & 13 \\
$<\$ 100$ & $19 *$ & $<5 \%$ & $21^{*}$
\end{tabular}

SOURCE: NCSL (2003a).

*Includes 18 states with no projected budget deficit. Data were unavailable for three states.

In April 2003, the NCSL reported that collective state budget deficits for FY 2003 could range from $\$ 22$ billion to $\$ 30$ billion. Thirteen states reported budget deficits in excess of 5 percent of general fund revenues. Projections for FY 2004 were more dire, with estimates ranging from $\$ 54$ billion to $\$ 78$ billion. California alone had an estimated budget deficit of $\$ 17.5$ billion, or roughly 21 percent of its general fund budget. For FY 2004, 26 states forecasted budget deficits greater than 5 percent of general fund revenue, while 13 of these forecasted deficits in excess of 10 percent of general fund revenue. Table 8 summarizes the forecasted FY 2004 budget deficits that were projected in April 2003, both in levels and as a percentage of general fund revenue.

The recession in the early 1990s was comparatively less disruptive to state coffers. The deficit between state tax revenues and expenditures (in 2002 dollars) was $\$ 11$ billion ( 0.14 percent of GDP) and $\$ 17$ billion ( 0.21 percent of GDP) in 1991 and 1992, respectively. The projected collective state budget deficits for FY 2004 are roughly five times greater ( 0.71 percent of GDP) than during the recession a decade ago.

The budget deficits have forced states to make drastic spending cuts on various programs, including education, Medicaid, and corrections. As discussed in the introduction, these cuts along with tax and fee increases and modest revenue growth have all led to improved state budget forecasts for FY 2004. Roughly half of all states have or are planning to make cuts in one or more of the above programs. Twenty-seven states have proposals to reduce or contain Medicaid costs. For example, Illinois reduced Medicaid funding by $\$ 205$ million, Kansas reduced services in mental health and disability services, and Massachusetts eliminated its MassHealth Basic insurance that left 50,000 people ineligible for Medicaid assistance. K-through-12 education spending is likely to be reduced in 21 states, and 26 states are considering cuts in higher education. The Connecticut governor has recommended a $\$ 104$ million decrease in K-through 12 education, Michigan's governor has proposed a 6.75 percent reduction in state aid to higher education institutions, and Tennessee has reduced higher education expenditures by $\$ 102$ million. These cuts, combined with tax and fee increases and modest revenue growth have led to improved state budget forecasts for FY 2004.

\section{What Caused the Budget Crises?}

Budget deficits are caused by a reduction in revenues, an increase in expenditures, or both. To understand the causes of the current crisis, one must look to the previous decade. Over the period 1993 to 2000 , state revenue collections grew markedly as a result of the unusually high levels of economic activity; thus many states were faced with budget surpluses; as a result, almost every state enacted large permanent tax cuts. The majority of cuts were on personal and corporate income taxes, although many states also reduced sales and excise taxes. Ten states enacted cuts totaling between 1 and 3 percent of total tax revenues, while 33 states enacted cuts in excess of 3 percent of total tax revenues. According to the Center on Budget and Policy Priorities, the tax cuts of the 1990s reduced actual state tax revenue by 8.2 percent. However, tax revenues continued to grow with the economic boom throughout the 1990s despite the broad reduction in tax rates across states. 


\section{Figure 3}

\section{Real Per Capita State Revenue and Expenditures, 1947-2002}

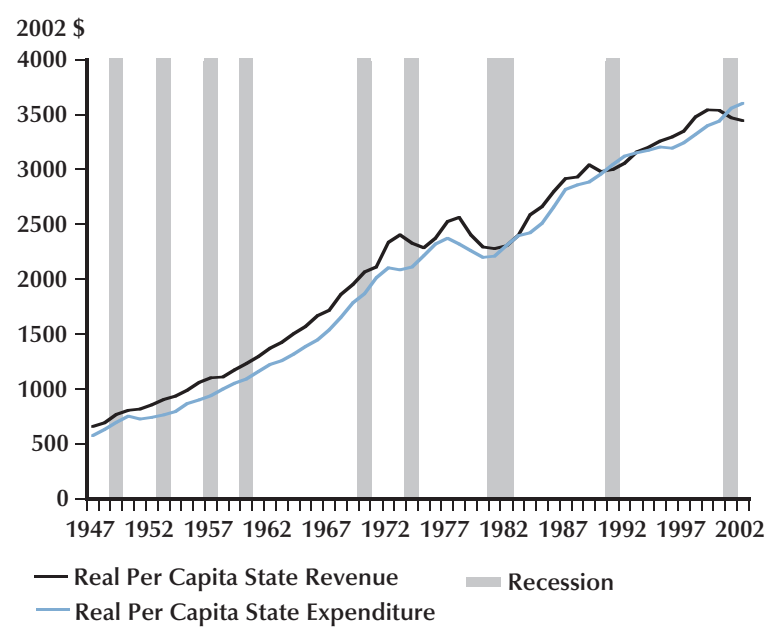

States had essentially financed permanent tax cuts with the temporary economic boom. The recession beginning March 2001 (NBER classification) and the stock market collapse throughout 2000 and 2001 have led to a reduction in personal and corporate incomes, capital gains, and consumption. States once flush with revenues quickly saw their coffers drained. Unlike the 1990-91 recession when nearly every state raised taxes in response to budget shortfalls, few states have raised taxes since the recent economic slowdown as a result of greater voter disdain for tax increases. And, in most cases, the tax increases have focused on relatively narrow and low-growth tax bases such as retail sales, alcohol, and tobacco, thus limiting both the short-run and long-run growth potential of new revenues. ${ }^{27}$ Fiscal pressures on the federal budget have also resulted in less intergovernmental aid to states from the federal government. Furthermore, states are partially responsible for covering the costs of homeland security in the wake of September 11, 2001. Slow economic growth, a weak stock market, an increase in homeland security responsibilities, and a greater reliance on weakening tax bases all continue to prolong states' budget crises.

The stock market collapse and the recent recession clearly affected the revenue side of state financing. However, are current budget deficits entirely

${ }^{27}$ For a discussion of the structural problems in state finance, see Knight, Kusko, and Rubin (2003).
Table 9

State Revenue and Expenditure Growth, 1998-2002

\begin{tabular}{ccc} 
Year & $\begin{array}{c}\text { Annual growth in } \\
\text { real per capita } \\
\text { revenues (\%) }\end{array}$ & $\begin{array}{c}\text { Annual growth in } \\
\text { real per capita } \\
\text { expenditure (\%) }\end{array}$ \\
\hline 1998 & 3.9 & 2.3 \\
1999 & 1.9 & 2.4 \\
2000 & -0.2 & 1.3 \\
2001 & -1.9 & 3.4 \\
2002 & -0.7 & 1.3 \\
\hline
\end{tabular}

due to a reduction in revenue, or has state expenditure growth also increased over the past decade, thereby widening the deficit between revenues and expenditures? Annual real per capita state expenditures and revenues from 1947 to 2002 are shown in Figure 3 along with NBER recessionary periods. ${ }^{28}$ The aggregate state budget deficit is at the far right of Figure 3, and it is much greater than the deficit present during the 1990-91 recession. Inspection suggests that the growth in real per capita expenditures during the 1990s was not greater than earlier decades. In fact, the average annual growth in real per capita state expenditures over the period 19922000 was 1.2 percent, compared with 3.2 percent and 1.5 percent in non-recession years during the 1980s and 1970s, respectively.

However, recent revenue and expenditure data reveal that expenditure growth did not slow in the wake of decreasing tax revenues. Annual growth in state per capita revenues and expenditures from 1998 to 2002 is shown in Table 9. While annual real expenditure growth averaged roughly 2 percent, annual real revenue growth from 2000 to 2002 was negative. This scenario occurred during other recessionary periods, as shown in Figure 3; however, state budget surpluses prior to this recent recession were smaller than those prior to earlier recessions, thus increasing the chances that a reduction in revenue would lead to a budget deficit. Currently and historically, state governments have continued to increase expenditures even through years of negative revenue growth.

States financed permanent tax cuts with the

\footnotetext{
28 Data are from the Office of Management and Budget (www.whitehouse.gov/omb/budget/fy2004/hist.html)
} 
economic boom of the 1990s, and the stock market collapse and the recent recession hit state budgets hard by reducing revenues from capital gains, personal and corporate income, and general sales taxes. The importance of income and sales tax revenues to state finances and the relatively high variability of these revenue sources over the business cycle amplified the budget shortfalls seen across the states. In addition, tax revenue reductions and the failure of state governments to curb recent expenditure growth in the wake of negative revenue growth are factors attributed to the current state budget crises.

\section{States' Response to the Crises}

State governments are implementing or considering various policies aimed at increasing revenue, including an increase in various tax rates. Fewer states have implemented or are considering rate hikes after this recession than during the 1990-91 recession, despite the fact that state budgets are in greater trouble now than a decade ago. In April 2003, the NCSL reported that six states have increased cigarette taxes and two states have increased alcohol taxes. Fourteen states were considering an increase in these taxes, and eleven states were debating an increase in the sales tax. Six states were looking at increases in personal income and corporate income tax rates. Rather than raising tax rates, several other states were considering ways to close tax loopholes and expand tax bases. The Nelson A. Rockefeller Institute of Government (2003) reported that, as of November 2003, eighteen states have raised taxes by $\$ 6.2$ billion for FY 2004 .

Given the reluctance of state government to raise traditional tax rates, states are pursuing other options in addition to traditional tax increases, some of which were discussed here earlier. Several states are considering the adoption or expansion of casino gaming, and others have or are proposing an increase in casino tax rates. Cutbacks or salary reductions for state employees are also common, as are cuts in education and health care. Tuition hikes are also occurring in many states, along with increases in license fees and vehicle registration fees. Ten states have also tapped into their RDFs during FY 2003. Finally, state governments also use what Petersen (2003) calls "smoke and mirror" efforts to deal with their current crises, such as using funds from the tobacco tax settlement and raiding state pension funds.

\section{CONCLUSIONS: PRELUDE TO MORE CRISES?}

While the current state budget crises are the most severe in the postwar era, states have faced other budget crises in the past. It thus seems reasonable that states would realize that favorable economic conditions cannot last forever and, therefore, implement revenue and expenditure policies that would allow them to weather periods of fiscal stress. Even when the current crises are resolved, however, there should be little doubt that states will again experience budget crises in the future. During economic booms, as in the 1990s, state lawmakers tend to cut tax rates while tax coffers are flush and make additional expenditure commitments that they have difficulty keeping when the economy slows. As economic conditions improve, state revenues will rise again. If the past is a guide, these revenues will be committed to ongoing spending programs or tax rates will be cut. The single step of raising taxes and fees is no panacea to the procyclical spend/cut pattern of state governments.

Furthermore, the set-up of state revenue systems does not bode well for long-term fiscal solvency. Many states are currently considering increases in sales and excise taxes. However, growth in this source of tax revenue has slowed in recent history as the economy moves toward services, which are traditionally exempt from state sales taxes. In addition, a continued decrease in the number of smokers questions the ability of cigarette tax increases to provide a reliable long-term source of revenue. Although personal and corporate income taxes trend with economic conditions, growth in corporate income tax revenues has decreased over the past 20 years, partly due to decreased tax rates but also due to tax avoidance actions taken by businesses. The cyclical variability of sales and income taxes also suggests that state governments will be faced with relatively greater revenue variability in the future as long as increasing portions of state revenues come from these sources.

\section{REFERENCES}

Ader, Jason N. Bear Stearns North American Gaming Almanac 2002-2003. Las Vegas: Huntington Press, 2003.

Advisory Commission on Intergovernmental Relations (ACIR). Significant Features of Fiscal Federalism. Washington, DC: 1987, 1994. 
Alm, James; McKee, Michael and Skidmore, Mark. "Fiscal Pressure, Tax Competition, and the Introduction of State Lotteries." National Tax Journal, December 1993, 46(4), pp. 463-76.

Clotfelter, Charles T. and Cook, Philip J. Selling Hope: State Lotteries in America. Cambridge: Harvard University Press, 1989.

Clotfelter, Charles T. and Cook, Philip J. "On the Economics of State Lotteries.” Journal of Economic Perspectives, Fall 1990, 4(4), pp. 105-19.

Crain, W. Mark. Volatile States: Institutions, Policy, and the Performance of American State Economies. Ann Arbor: University of Michigan Press, 2003.

Dye, Richard F. and McGuire, Therese J. "State Fiscal Systems and Business Cycles: Implications for Welfare Spending when the Next Recession Occurs." Discussion Paper 99-04, Urban Institute, Washington, DC, 1999.

Elder, Harold W. "Exploring the Tax Revolt: An Analysis of the Effects of Tax and Expenditure Limitations." Public Finance Quarterly, January 1992, 20(1), pp. 47-63.

Garrett, Thomas A. "Earmarking Lottery Revenues for Education: A New Test of Fungibility." Journal of Education Finance, Winter 2001, 26(3), pp. 219-38.

Gold, Steven D., ed. The Fiscal Crises of the States: Lessons for the Future. Washington, DC: Georgetown University Press, 1995.

Goolsbee, Austan. "In a World without Borders: The Impact of Taxes on Internet Commerce." Quarterly Journal of Economics, May 2000, 115(2), pp. 561-76.

Holcombe, Randall G. and Sobel, Russell S. Growth and Variability in State Tax Revenue: An Anatomy of State Fiscal Crises. Westport, CT: Greenwood Press, 1997.

Johnson, Nicholas. The State Tax Cuts of the 1990s, the Current Revenue Crisis, and Implications for State Services. Washington, DC: Center on Budget and Policy Priorities, November 2002.

Knight, Brian; Kusko, Andrea and Rubin, Laura. "The State and Local Sector: Problems and Prospects." State Tax Notes, August 2003, 29(6).
Levinson, Arik. "Balanced Budgets and Business Cycles: Evidence from U.S. States.” National Tax Journal, December 1998, 51(4), pp. 715-32.

National Conference of State Legislatures (NCSL). State Budget Update: April 2003. Washington, DC: National Conference of State Legislatures, April 2003a.

National Conference of State Legislatures. State Budget Update: November 2003. Washington, DC: National Conference of State Legislatures, November 2003b.

National Conference of State Legislatures. State Budget and Tax Actions 2003. Washington, DC: National Conference of State Legislatures, 2003c.

National Governors Association. Fiscal Survey of States: June 2003. Washington, DC: National Governors Association, June 2003.

Nelson A. Rockefeller Institute of Government. "2003 Tax and Budget Review." The Nelson A. Rockefeller Institute of Government State Fiscal Brief, December 2003, No. 69.

Petersen, John E. "Changing Red to Black: Deficit Closing Alchemy.” National Tax Journal, September 2003, 56(3), pp. 567-77.

Poterba, James M. "State Responses to Fiscal Crises: The Effects of Budgetary Institutions and Politics." Journal of Political Economy, August 1994, 102(4), pp. 799-821.

Rueben, Kim S. "The Effect of State Tax and Expenditure Limits on State and Local Governments." Ph.D Dissertation, Department of Economics, Massachusetts Institute of Technology, 1997.

Snell, Richard K.; Eckl, Corina and Williams, Graham. "State Spending in the 1990s." Report prepared for the National Conference of State Legislatures Fiscal Affairs Program, July 2003.

Sobel, Russell S. and Wagner, Gary A. "Cyclical Variability in State Government Revenue: Can Tax Reform Reduce It?" State Tax Notes, August 2003, 29(8), pp. 569-76.

Spindler, Charles. "The Lottery and Education: Robbing Peter to Pay Paul?" Public Budgeting and Finance, 1995 , 15(3), pp. 54-62. 
Szakmary, Andrew and Szakmary, Carol. "State Lotteries as a Source of Revenue: A Re-Examination." Southern

Economic Journal, April 1995, 64(4), pp. 1167-81.

Wagner, Gary A. "Are State Budget Stabilization Funds Only the Illusion of Savings? Evidence from Stationary Panel Data." Quarterly Review of Economics \& Finance, Summer 2003, 43(2), pp. 213-38. 
RE V I E W 